\title{
Effect of natural growth promoters on immunity, and biochemical and haematological parameters of broiler chickens
}

\author{
Syed Muddassar Hussain Gilani ${ }^{1 \star}$, Sitwat Zehra ${ }^{2}$, Faiz-ul-Hassan ${ }^{3}$, Saddia \\ Galani $^{2}$, Asma Ashraf ${ }^{4}$ \\ ${ }^{1}$ Department of Agriculture and Agribusiness Management, ${ }^{2}$ Karachi Institute of Biotechnology and Genetic Engineering \\ (KIBGE), University of Karachi, Karachi, ${ }^{3}$ Institute of Animal Sciences, University of Agriculture, Faisalabad, ${ }^{4}$ Department of \\ Zoology, Government College University, Faisalabad, Pakistan
}

${ }^{*}$ For correspondence: Email: gilani1294@gmail.com; Tel: 009-23218237926

Sent for review: 8 December 2017

Revised accepted: 19 March 2018

\begin{abstract}
Purpose: To investigate the efficacy of promising alternatives to antibiotic growth promoters (organic acids, phytobiotics, and their combinations) as feed additives in poultry feed.

Methods: Different feed treatments were formulated with organic acids, phytobiotics and their combinations, and their effects on blood profile, serum enzymes and immunity parameters were evaluated in broilers at 21 and 42 days of age.

Results: Cholesterol, triglyceride and HDL levels of the 21- and 42-day old broilers were significantly ( $p$ $<0.05)$ affected by the feed additives. The effect of albumin and albumin/globulin ratios varied significantly $(p<0.05)$ from that of the control group at 42 days of age. Haematological analysis did not show significant changes ( $p>0.05$ ) in parameters except hematocrit, $R B C, M C H, M C H C, W B C$ at age 21 days. However, among the serum enzymes assayed, only gamma-glutamyl transferase activity was altered for the modified feed group.

Conclusion: These results suggest that supplementation with organic acids and phytobiotics can be used as alternatives to antibiotic growth promoters without interfering with the overall health and performance of broilers.
\end{abstract}

Keywords: Broilers, Antibiotic growth promoters, Phytobiotics, Organic acids, Biochemical parameters

\begin{abstract}
This is an Open Access article that uses a funding model which does not charge readers or their institutions for access and distributed under the terms of the Creative Commons Attribution License (http://creativecommons.org/licenses/by/4.0) and the Budapest Open Access Initiative (http://www.budapestopenaccessinitiative.org/read), which permit unrestricted use, distribution, and reproduction in any medium, provided the original work is properly credited.
\end{abstract}

Tropical Journal of Pharmaceutical Research is indexed by Science Citation Index (SciSearch), Scopus, International Pharmaceutical Abstract, Chemical Abstracts, Embase, Index Copernicus, EBSCO, African Index Medicus, JournalSeek, Journal Citation Reports/Science Edition, Directory of Open Access Journals (DOAJ), African Journal Online, Bioline International, Open-J-Gate and Pharmacy Abstracts

\section{INTRODUCTION}

The use of antibiotic growth promoters (AGPs) in poultry feed was banned in 2006, notwithstanding their beneficial roles in growth performance and disease prevention in poultry, due to the development of resistance in bacteria and presence of drug residues in meat [1]. Efforts have been focused on the use of alternatives to AGPs such as organic acids and phytobiotics [2]. Organic acids and their blends (acetic acid, formic acid, lactic acid, propionic 
acid and isobutyric acid) can be used to enhance poultry production and performance through improved nutrient digestion and absorption by reducing enteric pathogenic microbial loads and intestinal $\mathrm{pH}$ in birds. The buffering capacity of diets enhanced by supplementation with organic acids contributes to the maintenance of good health status in poultry [3].

The content of active substances in the products may vary widely within phytobiotic feed additives, depending on the part of the plant used (e.g. seeds, leaf, root or bark); harvesting season, and geographical location [4]. The physiological effects of various active compounds derived from plants and their possible interactions have been investigated in terms of growth, production performance, immune response and gut health of animals [5,6]. Kidney and liver functions are efficiently regulated by phytobiotic supplementation. Overall, it has been observed that serum biochemical and hematological parameters are improved by inclusion of phytobiotics in broiler diets [7].

Serum biochemical and hematological parameters are reliable indicators of health status of animals, and may have important roles in diagnosis, prognosis, and treatments of poultry diseases. For example, alanine transaminase $(\mathrm{ALT})$ and aspartate aminotransferase (AST) are considered diagnostic enzymes for liver diseases [9]. These parameters are generally influenced by nutrition, season, climate change, age, sex, type of birds and management systems [8]. The present study was conducted to evaluate the effects of natural growth promoters (as alternatives to AGPs) on the health status of broiler chicks, with respect to biochemical, hematological, and serum enzyme parameters, and immunity against Newcastle disease (ND).

\section{EXPERIMENTAL}

\section{Bird husbandry}

A total 315 day-old Hubbard broiler chicks were purchased from a commercial hatchery. The birds were randomly divided into five groups, each group having 63 chicks with three replicates (21 birds/replicate). All experimental birds were vaccinated against infectious bronchitis, ND and infectious bursal disease according to the vaccine schedule provided by a local day-old Hubbard chick producing company (Mega Poultry Company Pvt.). The broiler birds were vaccinated against Newcastle disease at day 5 and day 26 of age for the estimation of ND titres, and at day 21 and 42 of age. All procedures used in the animal experiments were approved by
KIBGE Ethical Review Board (no. DG/AA-089) in accordance with the Care and Use of Agricultural Animals in Research [10].

\section{Experimental rations and formulations}

Two basal diets were formulated according to the Hubbard classic nutrient requirements and offered as broiler starter ( 0 - 21 days of age) and broiler finisher rations (21 to 42 days of age). Each diet was analysed as described by AOAC [11] for proximate composition [12]. The feed ingredients and chemical composition of the experimental diets are presented in Table 1. Birds were provided with iso-nitrogenous and isocaloric basal diets through the inclusion of different feed additives. Group 1 (Control) was given basal diet without AGP; Group 2 (AGP) received basal diet $+40 \mathrm{gm}$ AGP (virginimycine) per metric ton (mt) of feed; while Group 3 (organic acid group) had basal diet $+4 \mathrm{~kg}$ organic acids (blend of $11.5 \%$ propionic acid, 45 $\%$ formic acid, and $15 \%$ citric acid per mt of feed. Group 4 (phytobiotics) had basal diet +3 $\mathrm{kg}$ phytobiotics (blend of Zingiber officinale (ginger) and Glycyrrhiza glabra (liquorice), Withania somnifera (Ashwagandha), Camellia sinensis (green tea), Nigella sativa (black seed) per $\mathrm{mt}$ of feed. Group 5 (combination group) was given basal diet + combination (organic acids + phytobiotics at the same dose (per mt of feed) as Groups 3 and 4).

\section{Blood collection}

Each replicate of birds was reared in individual pens. Three birds were selected randomly from each group on day 21 and day 42 of age, and 2 $\mathrm{ml}$ blood samples were collected from each bird through the brachial vein, using sterile needles and syringes. The blood samples were put in properly labelled and sterilized anticoagulant (EDTA) tubes and used for haematological analysis. In addition, $2 \mathrm{ml}$ of blood was collected from each bird into tubes without anticoagulant, for estimation of biochemical and enzyme indices, as well as ND antibody titres. The bloodcontaining tubes were placed in slanting position at room temperature for $6 \mathrm{~h}$ and incubated overnight in the refrigerator at $4{ }^{\circ} \mathrm{C}$ to obtain serum. The serum samples were kept at $-20{ }^{\circ} \mathrm{C}$ prior to biochemical analysis.

\section{Assessment of biochemical indices}

The following biochemical analyses were estimated: total protein, albumin, globulin, creatinine, albumin/globulin ratio (AG ratio), glucose, cholesterol, triglyceride, high density lipoprotein (HDL), low density lipoprotein (LDL). 


\section{Evaluation of hematological indices}

The samples were subjected to hematological analysis with respect to hemoglobin $(\mathrm{Hb})$ concentration, packed cell volume (PCV), red blood cells (RBC), mean cell hemoglobin $(\mathrm{MCH})$, mean cell volume (MCV), mean cell $\mathrm{Hb}$ concentration (MCHC), white blood Cells (WBC), neutrophils, lymphocytes (LY), eosinophils, monocytes, basophils (BA), using Hematological Analyzer Sysmex XP- 100 (Japan).

\section{Determination of serum enzyme indices}

The serum samples were analyzed for AST, ALT and gamma-glutamyl transferase (GGT) using automatic Biochemical Analyzer (Clinic 200).

\section{Determination of ND virus antibodies (ND titres)}

Two-fold serial dilution of each serum sample was made in a 96-well microtitre plate. Serum dilutions were prepared ranging from 1: 2 to 1 : 48. Then, $25 \mu \mathrm{L}$ of buffer, $\mathrm{pH} 7.2-7.4,25 \mu \mathrm{L}$ of serum and $25 \mu \mathrm{L}$ of ND virus antigen were added to all wells except controls and incubated for 10 min at $37^{\circ} \mathrm{C}$. Erythrocyte suspension $(50 \mu \mathrm{L}, 0.5$ $\%$ ) was added to each well and left for $30 \mathrm{~min}$. A positive control serum, a negative control serum, erythrocytes and antigens were also included as controls. The highest dilution of serum causing complete inhibition of erythrocyte agglutination was recorded [13].

\section{Statistical analysis}

Statistix 8.1 software was employed for statistical analysis (one way ANOVA) in a completely randomized design. Treatment means were compared using Least Significant Difference (LSD) method for all pairwise comparisons. Statistically significant difference was determined at $p<0.05$.

Table 1: Feed additives of the experimental diets (starter and finisher rations)

\begin{tabular}{|c|c|c|c|c|c|}
\hline \multirow[t]{2}{*}{ Feed ingredient } & \multirow{2}{*}{$\begin{array}{l}\text { Starter } \\
\text { Inclusion (\%) }\end{array}$} & \multirow{2}{*}{$\begin{array}{c}\text { Finisher } \\
\text { Inclusion (\%) }\end{array}$} & \multirow[t]{2}{*}{ Nutrients } & \multicolumn{2}{|c|}{$\begin{array}{l}\text { Calculated } \\
\text { composition }\end{array}$} \\
\hline & & & & Starter & Finisher \\
\hline Corn Gluten & 59 & 62 & ${ }^{*} \mathrm{ME}^{8}, \mathrm{Kcal} / \mathrm{kg}$ & 2900 & 3000 \\
\hline Soya bean meal (44 \%) & 19.43 & 28 & Crude protein (\%) & 21.5 & 19.17 \\
\hline Canola meal & 10 & 0 & Calcium (\%) & 1 & 0.9 \\
\hline $\begin{array}{l}\text { Fish meal (55 \% crude } \\
\text { protein) }\end{array}$ & 3 & 0 & $\begin{array}{c}\text { Available phosphorous } \\
(\%)\end{array}$ & 0.47 & 0.4 \\
\hline $\begin{array}{l}\text { Corn gluten ( } 60 \% \text { crude } \\
\text { protein) }\end{array}$ & 3 & 2.5 & Dig. lysine (\%) & 1.19 & 1.07 \\
\hline${ }^{\star} \mathrm{PPM}^{\prime}$ ( $50 \%$ crude protein) & 2 & 2 & Dig. methionine (\%) & 0.54 & 0.56 \\
\hline Limestone & 1.3 & 1.4 & $\begin{array}{l}\text { Dig. Methionine + } \\
\text { cysteine (\%) }\end{array}$ & 0.88 & 0.88 \\
\hline Vegetable Oil & 0.36 & 1.6 & Dig. tryptophan (\%) & $0 . .23$ & 0.2 \\
\hline DL-Methionine & 0.18 & 0.26 & & & \\
\hline Lysine sulphate $55 \%$ & 0.47 & 0.39 & & & \\
\hline${ }^{*}$ Vitamin premix ${ }^{2}$ & 0.05 & 0.05 & & & \\
\hline${ }^{*}$ Mineral premix ${ }^{3}$ & 0.05 & 0.05 & & & \\
\hline L-threonine & 0.16 & 0.15 & & & \\
\hline Salt (Nacl) & 0.2 & 0.2 & & & \\
\hline Sodium-bi-carbonate & 0.25 & 0.23 & & & \\
\hline${ }^{*}$ Anti - coccidial $^{4}$ & 0.02 & 0 & & & \\
\hline${ }^{*}$ Anti - coccidial ${ }^{b}$ & 0 & 0.05 & & & \\
\hline${ }^{*} \mathrm{MDCP}^{6} 21 \%$ & 0.3 & 0.99 & & & \\
\hline Choline chloride $60 \%$ & 0.2 & 0.1 & & & \\
\hline Quantum Blue (phytase) & 0.02 & 0.02 & & & \\
\hline *Seldox' (antioxidant) & 0.015 & 0.015 & & & \\
\hline Total & 100 & 100 & & & \\
\hline \multicolumn{6}{|c|}{ 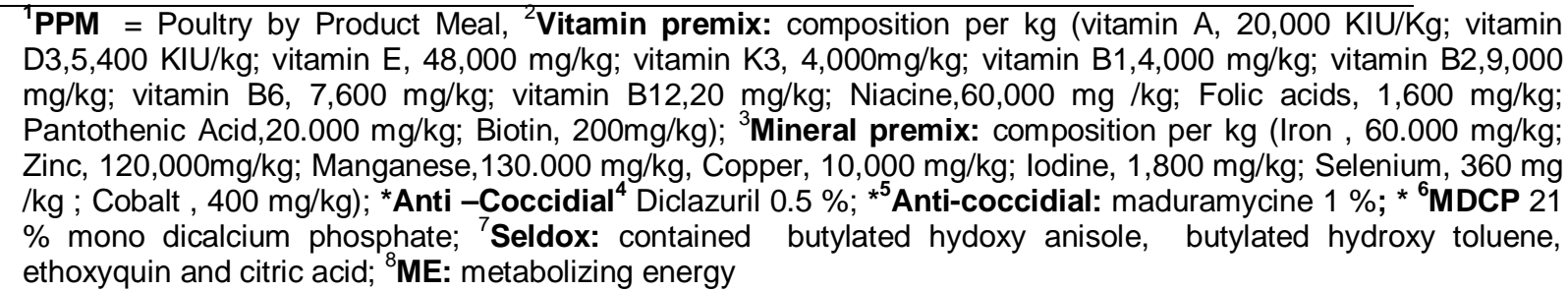 } \\
\hline
\end{tabular}




\section{RESULTS}

\section{Biochemical indices}

The results of serum biochemical analysis of birds in different groups revealed that cholesterol, triglyceride, HDL, LDL levels differed significantly $(p<0.05)$ among all feed groups at the $21^{\text {st }}$ and $42^{\text {nd }}$ days of age, except LDL at $42^{\text {nd }}$ day of age $(p>0.05)$. Phytobiotics, organic acids and their combinations resulted in decreased cholesterol, triglycerides and LDL, and increased HDL level at both stages (Table 2 and Table 3). Statistical analysis revealed significant differences $(p<0.05)$ in glucose, and nonsignificant differences $(p>0.05)$ in creatinine levels among the treatment groups (Table 3 ). Higher serum glucose was found in the phytobiotics group and their combinationsupplemented groups, while total proteins and globulin showed non-significant $(p>0.05)$ differences at both stages of rearing for all groups. Albumin and AG ratios were significantly $(p<0.05)$ different at 42 days, but the differences were non-significant at 21 days of age (Table 2 and Table 3).

\section{Haematological indices}

There were no significant differences in levels of haemoglobin, lymphocytes, neutrophils, eosinophils, monocytes, basophils and platelets among all treatment groups at 21 and 42 days of age (Tables 4 and 5). However, the levels of WBC and $\mathrm{MCHC}$ were significantly increased at 21 and 42 days of age in the organic acid- and phytobiotic-supplementation groups, as well as the combination group, when compared to the control group (Table 4 and Table 5).

\section{Serum enzyme indices}

No significant variations were found in serum concentration of the liver enzymes ALT and AST between the treatment groups, while GGT was significantly different in the treatment groups when compared with controls $(p<0.05)$ at 42 days of age (Table 6).

\section{ND virus antibody titres}

There were no significant changes in ND titres in the feed treatment groups at 21 days of age. However, at 42 days of age, only the phytobioticand combination-fed groups showed significantly $(p<0.05)$ higher ND titres than control (Table 7).

Table 2: Effect of different feed treatments on biochemical parameters of broiler chickens at 21 days of age

\begin{tabular}{|c|c|c|c|c|c|c|c|}
\hline Parameter & Control & AGP & $\begin{array}{l}\text { Organic } \\
\text { acids }\end{array}$ & Phytobiotics & Combination & *SEM & $P$ - value \\
\hline Cholesterol (mg/dL) & $65.81^{\mathrm{ab}}$ & $68.00^{\mathrm{a}}$ & $64.00^{\mathrm{ab}}$ & $55.33^{\mathrm{C}}$ & $62.00^{\circ}$ & 1.33 & 0.0005 \\
\hline Triglyceride (mg/dL) & $66.00^{\mathrm{a}}$ & $68.00^{\mathrm{a}}$ & $43.00^{c}$ & $48.00^{\mathrm{b}}$ & $38.67^{c}$ & 1.42 & 0.001 \\
\hline $\mathrm{HDL}(\mathrm{mg} / \mathrm{dL})$ & $35.67^{\mathrm{D}}$ & $36.27^{\mathrm{D}}$ & $39.77^{\mathrm{a}}$ & $40.67^{\mathrm{a}}$ & $41.33^{\mathrm{a}}$ & 1.08 & 0.01 \\
\hline LDL (mg/dL) & $44.63^{\mathrm{a}}$ & $32.07^{c}$ & $25.33^{a}$ & $34.67^{\mathrm{DC}}$ & $38.00^{\mathrm{b}}$ & 1.75 & 0.002 \\
\hline Creatinine $(\mathrm{mg} / \mathrm{dL})$ & $0.17^{\mathrm{ab}}$ & $0.27^{\mathrm{a}}$ & $0.10^{\mathrm{b}}$ & $0.17^{\mathrm{ab}}$ & $0.17^{\mathrm{ab}}$ & 0.039 & 0.133 \\
\hline Glucose random (mg/dL) & $156.37^{\mathrm{bc}}$ & $150.29^{c}$ & $133.44^{d}$ & $160.28^{b}$ & $186.37^{a}$ & 2.81 & 0.001 \\
\hline Total Protein (mg/dL) & $2.60^{\mathrm{a}}$ & $3.13^{\mathrm{a}}$ & $2.67^{\mathrm{a}}$ & $2.73^{\mathrm{a}}$ & $2.67^{\mathrm{a}}$ & 0.27 & 0.676 \\
\hline Albumin (mg/dL) & $1.23^{\mathrm{a}}$ & $1.47^{\mathrm{a}}$ & $1.30^{\mathrm{a}}$ & $1.27^{\mathrm{a}}$ & $1.20^{\mathrm{a}}$ & 0.12 & 0.633 \\
\hline Globulin (mg/dL) & $1.37^{\mathrm{a}}$ & $1.67^{\mathrm{a}}$ & $1.37^{\mathrm{a}}$ & $1.47^{\mathrm{a}}$ & $1.47^{\mathrm{a}}$ & 0.15 & 0.674 \\
\hline${ }^{* *} \mathrm{~A} / \mathrm{G}$ Ratio $(\mathrm{mg} / \mathrm{dL})$ & $0.87^{\mathrm{a}}$ & $0.87^{\mathrm{a}}$ & $0.93^{a}$ & $0.83^{a}$ & $0.77^{\mathrm{a}}$ & 0.06 & 0.462 \\
\hline
\end{tabular}

Means bearing different superscripts $(\mathrm{a}, \mathrm{b}, \mathrm{c})$ in a column differ significantly $(p<0.05)^{\star}$, ${ }^{\star} \mathrm{SEM}=$ standard error of the mean

Table 3: Effect of different feed treatments on biochemical parameters of broiler chickens at 42 days of age

\begin{tabular}{|c|c|c|c|c|c|c|c|}
\hline Parameter & Control & AGP & $\begin{array}{c}\text { Organic } \\
\text { acids }\end{array}$ & Phytobiotics & Combination & ${ }^{\star}$ SEM & $P$-value \\
\hline Cholesterol (mg/dL) & $66.59^{a}$ & $60.29^{b}$ & $57.00^{\mathrm{bc}}$ & $54.00^{c}$ & $64.33^{\mathrm{a}}$ & 1.19 & 0.0001 \\
\hline Triglyceride (mg/dL) & $66.67^{a}$ & $61.11^{\mathrm{D}}$ & $59.00^{C}$ & $53.00^{a}$ & $56.00^{e}$ & 0.65 & 0.0001 \\
\hline $\mathrm{HDL}(\mathrm{mg} / \mathrm{dL})$ & $35.33^{\mathrm{D}}$ & $36.00^{\mathrm{D}}$ & $37.00^{\mathrm{D}}$ & $39.33^{a}$ & $41.17^{\mathrm{a}}$ & 0.59 & 0.002 \\
\hline $\mathrm{LDL}(\mathrm{mg} / \mathrm{dL})$ & $17.00^{\mathrm{a}}$ & $14.0^{\mathrm{a}}$ & $15.66^{a}$ & $14.16^{a}$ & $16.66^{\mathrm{a}}$ & 1.08 & 0.244 \\
\hline Creatinine (mg/dL) & $0.37^{a}$ & $0.40^{\mathrm{a}}$ & $0.37^{\mathrm{a}}$ & $0.20^{a}$ & $0.50^{a}$ & 0.13 & 0.622 \\
\hline Glucose random (mg/dL) & $170.07^{\mathrm{D}}$ & $198.11^{a}$ & $169.77^{\mathrm{D}}$ & $193.00^{a}$ & $176.85^{\mathrm{b}}$ & 2.97 & 0.001 \\
\hline Albumin (mg/dL) & $1.57^{\mathrm{D}}$ & $1.53^{\mathrm{b}}$ & $1.43^{\mathrm{b}}$ & $1.43^{\mathrm{D}}$ & $1.88^{\mathrm{a}}$ & 0.07 & 0.01 \\
\hline Globulin (mg/dL) & $1.10^{\mathrm{a}}$ & $1.23^{a}$ & $1.47^{\mathrm{a}}$ & $1.30^{a}$ & $1.27^{\mathrm{a}}$ & 0.39 & 0.973 \\
\hline${ }^{* *} \mathrm{~A} / \mathrm{G}$ Ratio $(\mathrm{mg} / \mathrm{dL})$ & $1.40^{\mathrm{b}}$ & $1.27^{\mathrm{b}}$ & $1.07^{\mathrm{b}}$ & $1.33^{\mathrm{b}}$ & $2.30^{\mathrm{a}}$ & 0.25 & 0.04 \\
\hline
\end{tabular}

Means bearing different superscripts $(a, b, c)$ in a column differ significantly $(p<0.05)^{\star}$, ${ }^{\star}$ SEM; standard error of the mean, ${ }^{* *} \mathrm{~A} / \mathrm{G}$ ratio; albumin/globulin ratio 
Table 4: Effect of different feed treatments on haematological parameters of broiler chickens at 21 days of age

\begin{tabular}{|c|c|c|c|c|c|c|c|}
\hline Parameter & Control & AGP & $\begin{array}{c}\text { Organic } \\
\text { acids }\end{array}$ & Phytobiotics & Combination & *SEM & P- value \\
\hline Haemoglobin (mg/dL) & $9.13^{b}$ & $10.00^{\mathrm{ab}}$ & $10.04^{\mathrm{a}}$ & $9.77^{\text {ab }}$ & $10.07^{\mathrm{a}}$ & 0.27 & 0.177 \\
\hline Haematocrit (\%) & $27.93^{\mathrm{C}}$ & $30.10^{\mathrm{bc}}$ & $34.40^{\mathrm{a}}$ & $31.33^{\mathrm{ab}}$ & $31.20^{\mathrm{abc}}$ & 1.07 & 0.021 \\
\hline Red blood cells $\left(10^{12} / \mathrm{L}\right)$ & $2.16^{\mathrm{b}}$ & $2.33^{\mathrm{D}}$ & $2.64^{\mathrm{a}}$ & $2.43^{\mathrm{ab}}$ & $2.44^{\mathrm{ab}}$ & 0.09 & 0.05 \\
\hline${ }^{*} \mathrm{MCV}(\mathrm{FL})$ & $127.00^{\mathrm{a}}$ & $129.00^{\mathrm{a}}$ & $129.50^{\mathrm{a}}$ & $128.33^{a}$ & $129.00^{\mathrm{a}}$ & 1.38 & 0.741 \\
\hline${ }^{* *} \mathrm{MCHC}(\%)$ & $32.0^{\mathrm{bc}}$ & $33.47^{\mathrm{ab}}$ & $34.00^{\mathrm{a}}$ & $31.26^{\mathrm{C}}$ & $32.44^{\mathrm{abc}}$ & 0.51 & 0.023 \\
\hline${ }^{\star * *} \mathrm{MCH}(\mathrm{PG})$ & $41.00^{\mathrm{bc}}$ & $43.39^{a}$ & $43.00^{\mathrm{ab}}$ & $39.67^{c}$ & $42.00^{\mathrm{abc}}$ & 0.75 & 0.723 \\
\hline White blood cells $\left(10^{y} / \mathrm{L}\right)$ & $253.95^{\mathrm{b}}$ & $254.56^{\mathrm{b}}$ & $283.79^{a}$ & $287.13^{a}$ & $289.84^{a}$ & 2.18 & 0.001 \\
\hline Neutrophils (\%) & $2.00^{\mathrm{a}}$ & $3.33^{\mathrm{a}}$ & $2.95^{\mathrm{a}}$ & $2.92^{\mathrm{a}}$ & $2.66^{\mathrm{a}}$ & 0.49 & 0.45 \\
\hline Lymphocytes (\%) & $92.33^{\mathrm{a}}$ & $91.33^{a}$ & $94.33^{\mathrm{a}}$ & $94.00^{\mathrm{a}}$ & $94.33^{\mathrm{s}}$ & 1.04 & 0.303 \\
\hline Eosinophils (\%) & $1.04^{\mathrm{a}}$ & $1.03^{\mathrm{a}}$ & $1 . .05^{\mathrm{a}}$ & $1.05^{\mathrm{a}}$ & $1.03^{\mathrm{a}}$ & 0.01 & 0.773 \\
\hline Monocytes (\%) & $1.09^{\mathrm{a}}$ & $1.13^{\mathrm{a}}$ & $1.15^{\mathrm{a}}$ & $1.15^{\mathrm{a}}$ & $1.21^{\mathrm{a}}$ & 0.09 & 0.926 \\
\hline Basophils (\%) & $0.48^{a}$ & $0.52^{\mathrm{a}}$ & $0.40^{\mathrm{a}}$ & $0.56^{a}$ & $0.59^{a}$ & 0.1 & 0.733 \\
\hline Platelets $\left(10^{y} / \mathrm{L}\right)$ & $10000.0^{\mathrm{a}}$ & $9666.7^{a}$ & $10000.3^{a}$ & $10666.03^{a}$ & $11000.0^{a}$ & 494.41 & 0.364 \\
\hline
\end{tabular}

Means bearing different superscripts $(\mathrm{a}, \mathrm{b}, \mathrm{c})$ in a column differ significantly $(p<0.05)^{\star}$, ${ }^{\star} \mathrm{SEM}=$ standard error of the mean

Table 5: Effect of different feed treatments on haematological parameters of broiler chickens at 42 days of age

\begin{tabular}{|c|c|c|c|c|c|c|c|}
\hline Parameter & Control & AGP & $\begin{array}{c}\text { Organic } \\
\text { acidss }\end{array}$ & Phytobiotics & Combination & ${ }^{\star}$ SEM & $P$ - value \\
\hline Haemoglobin (mg/dL) & $8.50^{\mathrm{a}}$ & $8.93^{\mathrm{a}}$ & $8.23^{\mathrm{ab}}$ & $7.33^{\circ}$ & $8.30^{\mathrm{ab}}$ & 0.35 & 0.089 \\
\hline Haematocrit (\%) & $27.67^{\mathrm{ab}}$ & $29.93^{a}$ & $27.10^{\mathrm{ab}}$ & $25.20^{\mathrm{b}}$ & $27.87^{\mathrm{ab}}$ & 1.13 & 0.133 \\
\hline Red blood cells $\left(10^{12} / \mathrm{L}\right)$ & $2.05^{\mathrm{a}}$ & $2.14^{\mathrm{a}}$ & $2.02^{a}$ & $1.87^{\mathrm{a}}$ & $2.15^{\mathrm{a}}$ & 0.09 & 0.334 \\
\hline${ }^{*} \mathrm{MCV}(\mathrm{FL})$ & $129.07^{\mathrm{D}}$ & $138.74^{a}$ & $134.00^{\mathrm{ab}}$ & $134.83^{\mathrm{ab}}$ & $136.10^{a}$ & 1.91 & 0.05 \\
\hline${ }^{* *} \mathrm{MCHC}(\%)$ & $29.80^{\text {ab }}$ & $30.07^{\mathrm{ab}}$ & $30.33^{a}$ & $29.13^{\mathrm{b}}$ & $30.70^{a}$ & 0.31 & 0.04 \\
\hline${ }^{* * *} \mathrm{MCH}(\mathrm{PG})$ & $39.63^{\mathrm{b}}$ & $41.77^{\mathrm{a}}$ & $40.70^{\mathrm{ab}}$ & $39.23^{\mathrm{b}}$ & $40.53^{\mathrm{ab}}$ & 0.52 & 0.05 \\
\hline White blood cells $\left(10^{y} / \mathrm{L}\right)$ & $250.67^{d}$ & $258.67^{c}$ & $266.00^{\mathrm{ab}}$ & $261.00^{\mathrm{bc}}$ & $266.47^{a}$ & 1.73 & 0.04 \\
\hline Neutrophils (\%) & $3.66^{\mathrm{a}}$ & $4.3^{\mathrm{a}}$ & $3.00^{\mathrm{a}}$ & $3.66^{\mathrm{a}}$ & $3.33^{\mathrm{a}}$ & 0.53 & 0.53 \\
\hline Lymphocytes (\%) & $93.33^{\mathrm{a}}$ & $93.67^{\mathrm{a}}$ & $95.00^{\mathrm{a}}$ & $94.33^{a}$ & $94.33^{\mathrm{a}}$ & 0.9 & 0.722 \\
\hline Eosinophils (\%) & $1.05^{\mathrm{a}}$ & $1.08^{\mathrm{a}}$ & $1.06^{\mathrm{a}}$ & $1.07^{\mathrm{a}}$ & $1.07^{\mathrm{a}}$ & 0.02 & 0.936 \\
\hline Monocytes (\%) & $1.25^{\mathrm{a}}$ & $1.33^{\mathrm{a}}$ & $1.10^{\mathrm{a}}$ & $1.44^{\mathrm{a}}$ & $1.23^{\mathrm{a}}$ & 0.17 & 0.712 \\
\hline Basophils (\%) & $0.63^{b}$ & $0.85^{a}$ & $0.77^{\mathrm{ab}}$ & $0.79^{\mathrm{ab}}$ & $0.80^{\mathrm{ab}}$ & 0.06 & 0.278 \\
\hline Platelets $\left(10^{y} / \mathrm{L}\right)$ & $10000.0^{\mathrm{a}}$ & $11666.6^{a}$ & $11333.3^{a}$ & $11000.0^{a}$ & $11800.0^{a}$ & 694.58 & 0.424 \\
\hline
\end{tabular}

Means bearing different superscripts $(a, b, c)$ in a column differ significantly $(p<0.05)^{\star}$; ${ }^{*} \mathrm{SEM}$; standard error of the mean

Table 6: Effect of different feed treatments on serum enzymes of broiler chickens at 42 days of age

\begin{tabular}{lccccccc}
\hline Parameter & Control & AGP & Organic acid & Phytobiotic & Combination & ${ }^{*}$ SEM & $\boldsymbol{P}$ - value \\
\hline ALT (U/L) & $4.00^{\mathrm{a}}$ & $3.00^{\mathrm{a}}$ & $4.50^{\mathrm{a}}$ & $4.00^{\mathrm{a}}$ & $2.50^{\mathrm{a}}$ & 1.14 & 0.723 \\
AST (U/L) & $2.67^{\mathrm{ab}}$ & $259.33^{\mathrm{ab}}$ & $232.00^{\mathrm{b}}$ & $277.33^{\mathrm{a}}$ & $303.00^{\mathrm{a}}$ & 14.34 & 0.058 \\
${ }^{*} \mathrm{GGT}(\mathrm{U} / \mathrm{L})$ & $16^{\mathrm{c}}$ & $20^{\mathrm{b}}$ & $24^{\mathrm{a}}$ & $20.5^{\mathrm{b}}$ & $25^{\mathrm{a}}$ & 1.1 & 0.001 \\
\hline
\end{tabular}

Means bearing different superscripts $(\mathrm{a}, \mathrm{b}, \mathrm{c})$ in a column differ significantly $(p<0.05)^{\star}$, ${ }^{*} \mathrm{SEM}$; Standard error of the mean *GGT: Gamma-glutamyl transpeptidase

Table 7: Effect of different feed treatments on Newcastle disease titers of broiler chickens at 21 and 42 days of age

\begin{tabular}{|c|c|c|c|c|c|c|c|}
\hline ND titre & Control & AGP & $\begin{array}{c}\text { Organic } \\
\text { acid }\end{array}$ & Phytobiotics & Combination & ${ }^{*}$ SEM & $P$-value \\
\hline At 21 days of age & $3.33^{\mathrm{a}}$ & $3.66^{a}$ & $4.00^{\mathrm{a}}$ & $4.66^{\mathrm{a}}$ & $4.33^{\mathrm{a}}$ & 0.471 & 0.351 \\
\hline At 42 days of age & $3.66^{\mathrm{D}}$ & $5.00^{\mathrm{a}}$ & $5.33^{a}$ & $6.00^{\mathrm{a}}$ & $5.66^{a}$ & .365 & 0.009 \\
\hline
\end{tabular}

\section{DISCUSSION}

The results of this study demonstrate that supplementation of broiler feed with organic acids and phytobiotics may serve as effective alternative to synthetic antibiotics. The inclusion of phytobiotics such as green tea leaves, peppermint, and roots of Glycyrrhiza glabra in the diets of broilers reduced their serum cholesterol, triglycerides, and LDL, and improved their serum HDL levels. This may be attributed to 
the unique properties of phytobiotics, such as anti-atherosclerotic, antimicrobial, and immunemodulatory potential [14]. Different phytobiotics such as black seed [15], cumin seed [7], and ginger [16] have been associated with hypocholesterolemic effects. Plants have volatile oils which can inhibit the activity of 3- hydroxy-3methylglutaryl-coenzyme A reductase (HMGCoA reductase), a liver enzyme that regulates the biosynthesis of cholesterol, thereby reducing its level in the serum [17].

It is evident from the results that organic acid inclusion to broiler feeds significantly reduced the cholesterol and total blood lipids profile of the chicks at 21 and 42 days of age. This reduction may be due to decreases in gut $\mathrm{pH}$. Reduction in gut $\mathrm{pH}$ may interfere with the activities of microbial enzymes in the gut, thereby stimulating the bacterial cells to expend energy to expel the protons, leading to an intracellular accumulation [18].

In addition, the results of this study suggest that glucose level was significantly enhanced in the phytobiotic-supplemented group, relative to the control group at 21 and 42 days of age. This is consistent with the hyperglycemic activity of phytobiotics [19].

The supplementation of fennel and ginger had no significant effects on serum lymphocytes, eosinophils, monocytes and basophils of the birds. However, PCV, RBC and WBC were significantly increased by supplementation with organic acids at 21 and 42 days of age, most likely due to their antimicrobial interactions and stimulation of immune system resulting in enhanced immunity [20,21]. A phytobiotic such as licorice is used as blood purifier and immunity enhancer because it boosts white blood cells and ultimately increases interferon levels. The results of the current investigation support the fact that supplementation of feed with Ashwagandha root powder may protect RBC from oxidative stress due to its antioxidant activity [22].

Elevated levels of ALT and AST are sensitive indicators of hepatocellular disease. In this study, there were no significant changes in the serum levels of ALT and AST in the treatment groups when compared to control. Interestingly, although there were significant changes in GGT levels in the treatments groups, the birds were in good health without biliary cholestasis and duct hyperplasia. However, the diagnostic value of changes in GGT for hepatic injury depends on species of birds [23].
Immunity is a key factor for overcoming the problem of infections in poultry so as to enhance the growth performance and health status of poultry. The results obtained in the current investigation revealed that phytobiotics supplementation provide several compounds which may improving ND and IBD titres, and ultimately improve immunity by preventing liver damage and lipid peroxidation. Supplementation with black seed [16] and ginger rhizome has been proven to improve the immunity in birds through increased antibody production against ND virus [24].

\section{CONCLUSION}

Phytobiotics and their combination may boost the immunity and health of birds without any pronounced pathological conditions and changes in the blood profile of broiler chicks. This shows that phytobiotics are potential alternatives to AGPs.

\section{DECLARATIONS}

\section{Acknowledgement}

The authors would like to thank Ideal Feeds and Experimental Units, Karachi for providing the research facilities for this work.

\section{Conflict of Interest}

No conflict of interest associated with this work.

\section{Contribution of Authors}

The authors declare that this work was done by the authors named in this article and all liabilities pertaining to claims relating to the content of this article will be borne by them.

\section{REFERENCES}

1. Hashemi S, Davoodi H. Phytogenics as new class of feed additive in poultry industry. J Anim Vet Adv 2010; 9: 2295-2304.

2. Elagib H, El-Amin W, Malik HE. Effect of dietary garlic (Allium sativum) supplementation as feed additive on broiler performance and blood profile. J Anim Sci Adv 2013; 3: 58-64.

3. Papatsiros V, Christodoulopoulos G, Filippopoulos L. The use of organic acids in monogastric animals (swine and rabbits). J Cell Anim Biol 2012; 6: 154-159.

4. Karangiya V, Savsani $H$, Patil SS, Garg D, Murthy $K$, Ribadiya $N$, Vekariya $S$. Effect of dietary supplementation of garlic, ginger and their combination 
on feed intake, growth performance and economics in commercial broilers. Vet World 2016; 9: 245-250.

5. Ghazalah A, Ali A. Rosemary leaves as a dietary supplement for growth in broiler chickens. Int $\mathrm{J}$ Poul Sci 2008; 7: 234-239.

6. Figueiredo AC, Barroso JG, Pedro LG, Scheffer JJ. Factors affecting secondary metabolite production in plants: volatile components and essential oils. Flavour Fragr J 2008; 23: 213-226.

7. Al-Kassie GAM. The effect of thyme and cinnamon on the microbial balance in gastro intestinal tract on broiler chicks. Int J Poult Sci 2010; 9: 495-498.

8. Yokus, B, Cakir DU, Kanay Z, Gulten T, Uysal E. Effects of seasonal and physiological variations on the serum chemistry, vitamins and thyroid hormone concentrations in sheep. J Vet Med 2006; 53: 271-276.

9. Al-Jaff FK. Effect of coriander seeds as diet ingredient on blood parameters of broiler chicks raised under high ambient temperature. Int J Poult Sci 2011; 10: 82-86.

10. FASS. Guide for the care and use of agricultural animals in research and teaching. 3rd Ed. Federation of animal sciences societies. 2010. Publ. Sanoy, IL,USA.

11. AOAC. Animal Feed. In: Official methods of analysis. 18th Edition, Association of official Analytical Chemists, Gaithersburg, USA, 2005 ; pp 27-48.

12. Ghazalah A, Atta A, Elkloub K, Moustafa ME, Shata RF. Effect of dietary supplementation of organic acids on performance, nutrients digestibility and health of broiler chicks. Int J Poul Sci 2011; 10: 176-184.

13. OIE. Newcastle disease. Manual of Diagnostic Tests and Vaccines for Terrestrial Animals. Chapter 2.3. 2012. 14.http://www.oie.int/ international-standardsetting/terrestrial- manual/access-online.

14. Sharifi SD, Saeedeh H, Khorsandi A, Khadem A, Salehi $A$, Moslehi HR. The effect of four medicinal plants on the performance, blood biochemical traits and ileal microflora of broiler chicks. Vet Arhiv 2013; 83: 69-80.
15. Yaseen SA. Potential antiviral activity of Nigella sativa extracts. Irqi J Vet Sci 2003; 17:37-40.

16. Saeid JM, Mohamed AB, Al-Baddy MA. Effect of aqueous extract of ginger (Zingiber officinale) on blood biochemistry parameters of broiler. Int J Poult Sci 2010; 9: 944-947.

17. Fujioka T, Kondou R, Fukuhara A. Efficacy of glycyrrhizin suppository for treatment of chronic hepatitis C: a pilot study. Hepatol Res 2003; 26: 103-117.

18. Young KM, Foegeding PM. Acetic, lactic and citric acids and $\mathrm{pH}$ inhibition of Listeria monocytogenes Scott and the effect on intracellular $\mathrm{pH}$. J Appl Bacteriol 1993; 74 : 515-520.

19. Mehrdad R, Khalilia M, Mahdavia F. The effect of chronic administration of Withania somnifera on learning and memory deficits of diabetic rats. J Alzheimers Dement 2006; 2: 231.

20. Nasiroleslami M, M Torki. Including Essential Oils of Fennel (Foeniculum Vulgare) and Ginger (Zingiber Officinale) to Diet and Evaluating Performance of Laying Hens, White Blood Cell Count and Egg Quality Characteristics. Adv Environ Biol 2010; 4: 341-345.

21. Zareshahneh AK, Abdelahi MR, Kamyab AR, Nikkhah A. Effect of different levels of bacterial probiotics on broilers performance and some of blood factors. J Agric Sci Nat Res 2007; 14:162-170.

22. Sujatha V, Pandurang J, Rastogi, SK, Madan AK, Maini $S$, Ravikanth K. Amelioration of oxidative stress in broilers during summer. Biotechnol Anim Husbandry 2010; 26: 361-381.

23. Tennant BC. Hepatic Function. In: Clinical Biochemistry of Domestic Animals. (Kaneko JJ, Harvey JW, Bruss ML. Eds.) 5th ed., Academic Press. San Diego, London, Boston, New York, Sydney, Tokyo, Toronto.1997; pp. 327-352.

24. Azhir D, Zakeri A, Kargare-Rezapour A. Effect of ginger powder rhizome on humoral immunity of broiler chickens. Eur J Exp Biol 2012; 2: 2090-2092. 